\title{
TITLE:
}

\section{On Sorption of Gases and Liquids in Glassy Polymers}

$\operatorname{AUTHOR}(\mathrm{S})$ :

関本, 謙; Leibler, Ludwik

\section{CITATION:}

関本, 謙 ...[et al]. On Sorption of Gases and Liquids in Glassy Polymers. 物性研究 1994, 62(2): 344-346

ISSUE DATE:

1994-05-20

URL:

http://hdl.handle.net/2433/95318

RIGHT: 
On Sorption of Gases and Liquids in

Glassy Polymers

\section{E.S.P.C.I.(France) Ludwik Leibler and 名大·応物 関本謙}

\section{Introduction}

・高分子系のガラス化のレオロジーの話題である。高分子系では、低分子系と違ってガラス 転移点より高温でも絡み合いの効果のためにゴム状の固体的性質を示す。十分高温になって初 めてサラサラした液体のようにふるまう。

・ このような系では (少なくともガラス転移点より上では) いわゆる時間-温度等価性が成立 つ。即ちある温度で得られた時間的緩和のデータは温度に依存するシフト因子を用い別の温度 での別の時間領域の緩和デー夕に読み替えられる。他方、結晶状態以外での高分子はある範囲 の量の低分子 (溶媒) を取り込む事ができ、ガラス転移温度もこれに応じて変わる。このよう な溶媒は plasticizer と呼ばれてきた。

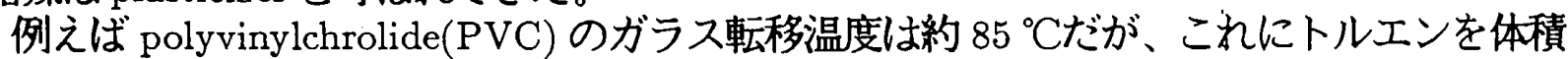

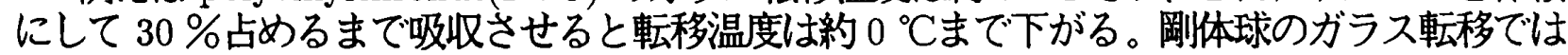
密度が温度目盛りの役をしたが、高分子系では密度と温度は独立にガラス化を制御する変数た れるところが違う。

そこで今度は温度-密度「等価性」を想像できる。対温度の熱力学応答が、密度を変えると あたかも温度軸をシフトしたように扱えると近似するのである。これは時間-温度等価性はどで ないにしても、良い定量的な第 0 近似である事を以下で等温吸収曲線の場合に示す。

\section{Excess Sorption}

実験はゴム状態或いはガラス状態の高分子を低分子溶媒蒸気の雾囲気の中に置き、温度 $T$ 一定で蒸気圧 $P$ を「っくりと」変えながら、高分子へ取り込まれた量を測定するものである。 但し、ゆっくりととは普通の実験の時間スケール（例えば 50 時間以内）でゆっくりとという意 味で、ガラスの非平衡性がみえなくなるほど長時間ではないとする。蒸気圧を変える事は飽和 （液化）状態を規準にした化学ポテンシャル $\Delta \mu_{0}$ を

$$
\Delta \mu_{0}=k_{B} T \log \frac{P}{P_{0}(T)}
$$

と変える事である。ここで $P_{0}(T)$ は飽和蒸気在である。

図 1 には polyvinyl benzoateによる二酸化炭素の等温吸収量が飽和蒸気圧で規格化した蒸 気圧の関数として示されている [1]。各温度の共通線 (下に凸の点線で補外されているもの) 部 分は高分子液体の分子場近似（フローリー理論 [2]）でほぼ満足に説明される。ところがある 蒸気恃以下で等温吸収線は前者から上に外れゼロ蒸気圧付近でやっと乾燥状態に達する。この 外れる所はちょうど（溶媒を含む）高分子のガラス転移点である。

・ 從来、この高分子液体理論からの外れは、溶媒を特に強くとりこむサイトがガラス転移と 共に出現するためであると想像されてきた。いくつかの調節パラメー夕を操作する事によって 実験デー夕と合わす試みが長年なされてきた。

われわれはそういう微視的な变化を仮定する事なしに、溶媒の吸収を準熱力学的に化学平 衡条件から導こうとする。準熱力学的というのは次の意味である。いま系がガラス状態に十分 入ってしまったとすると、実験の時間スケールにくらべて、ガラス的緩和は（緩和時間に広が りがあるとしても) おしなべて十分ゆっくりしているだろう。そのような状態では粘性率はガ ラス転移点近傍のように大きくはない。そのかわり、凍り付いた自由度の束縛分だけ弾性常数 が大きくなっている。例えばゴム状態の浸透体積弾性率 $K \sim 10^{5.5} \mathrm{dyn} / \mathrm{cm}^{2}$ からガラス状態で は $K \sim 10^{10} \mathrm{dyn} / \mathrm{cm}^{2}$ 位に増加する。ただし、硬くなるといっても変位が凍結される(剛体化) 
のではなく、弾性体としての応答が著しく強くなった系として扱うのである。

吸収量を決めるため次の諸関係を用いる。

(i) 溶媒に関する化学平衡条件。 $\Delta \mu$ を純溶媒を規準とした高分子中での溶媒の化学ポテンシャ ルとすると、

$$
\Delta \mu=\Delta \mu_{0}(T, P) .
$$

（ii）高分子中での溶媒の浔透圧 $\pi$ と化学ポテンシャルの関係。（ $v_{1}$ は溶媒の比体積で、非圧縮を 仮定する。)

$$
\Delta \mu=-v_{1} \pi .
$$

（iii）浸透体積弾性率 $K$ と浸透圧の関係。（ $\phi_{p}$ は高分子溶媒系中の高分子の正味体積分率。）

$$
K=\phi_{p} \frac{\partial \pi}{\partial \phi_{p}} .
$$

(iv) フローリー理論での弾性率 $\left(K_{F}\left(T, \phi_{p}\right)\right.$ とする-詳細は省く [2] $)$ からのガラス状態での弾 性率の増加分 $\delta K$ 。これは密度に依存するガラス転移温度 $\left(T_{g}\left(\phi_{p}\right)\right.$ で表す) と温度とのか ねあいで、T>T $T_{g}\left(\phi_{p}\right)$ ならゼロ、 $T<T_{g}\left(\phi_{p}\right)$ なら正の一定值 (例えば $\left.10^{10} \mathrm{dyn} / \mathrm{cm}^{2}\right)$ と する。これが温度一密度「等価性」の近似である。

· $\phi_{p}$ に関する積分によって、弾性率から逆に浸透圧を求め、これを化学平衡の条件に代入す ると、実験に比較すべき吸収量-規格化蒸気圧の曲線が描ける。フローリ一理論の部分を含め て、別の独立な実験からパラメー夕をあらかじめ与える事ができ、それをもちいた理論一実験 の比較はとても良い。図2にはPVC が vinylchrolide. 低分子を吸収する場合の実験 [3] と理論 [4]の比較を示す。ここには示さないが、ガラス転移での熱容量の跳びも $\Delta \mu を$ 更に $\phi_{p}$ で積分す る事により求められ、実験值を定量的に再現できる [4]。

\section{Summary}

・ゴム状高分子は冷やすか、短時間で見るか、また溶媒を取り去って行くかするとガラス状 態に入る。この状態を大きな弾性定数を持つ弾性体として準熱力学的に扱う事により、ガラス 状高分子による吸収実験を調節パラメータなしで、定量的に再現できた。従来の特異的な吸収 サイトは仮定する必要がない。この視点の変更が本研究の主たる価値である。

・ガラスの非平衡性がより顕著にあらわれるのはガラス転移をまさに含む過程であろう。溶 媒吸収のカイネテイックスやそこでの異方的内部歪、熱履歴の効果等々、ガラス転移のレオロ ジーに関する現象は更に明らかにされるであろう。

\section{References}

1. Kamiya, Y., Barlow, J.W., Paul, D.R., J. Polym. Sci., Polym. Phys. 1986, $24,535$.

2. Flory, P. J. "Principles of Polymer Chemistry" (Cornell Univ. Press, Ithaca N. Y., 1953).

3. Berens, A. R. Polym. Eng. Sci. 1980, 20, 95.

4. Leibler, L. and Sekimoto, K. Macromolecules (Communication), in press. 
研究会報告

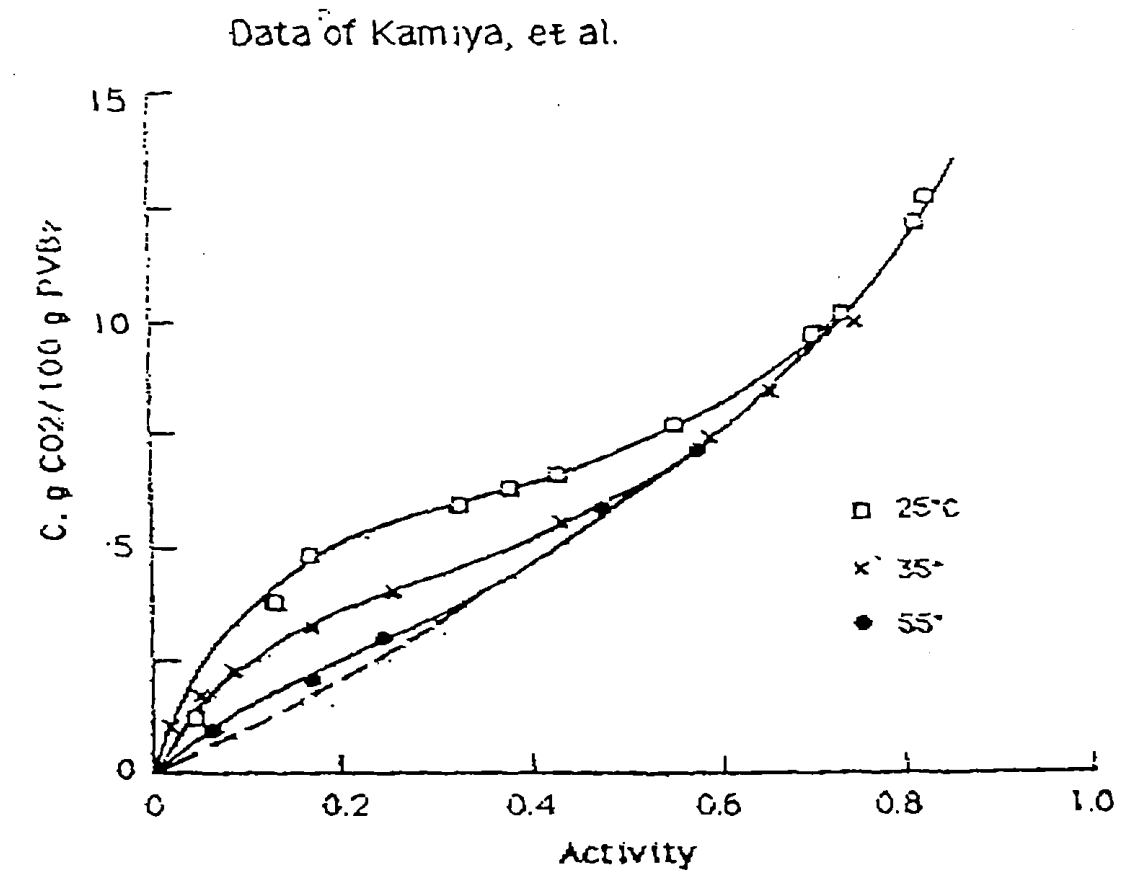

Fig. 1

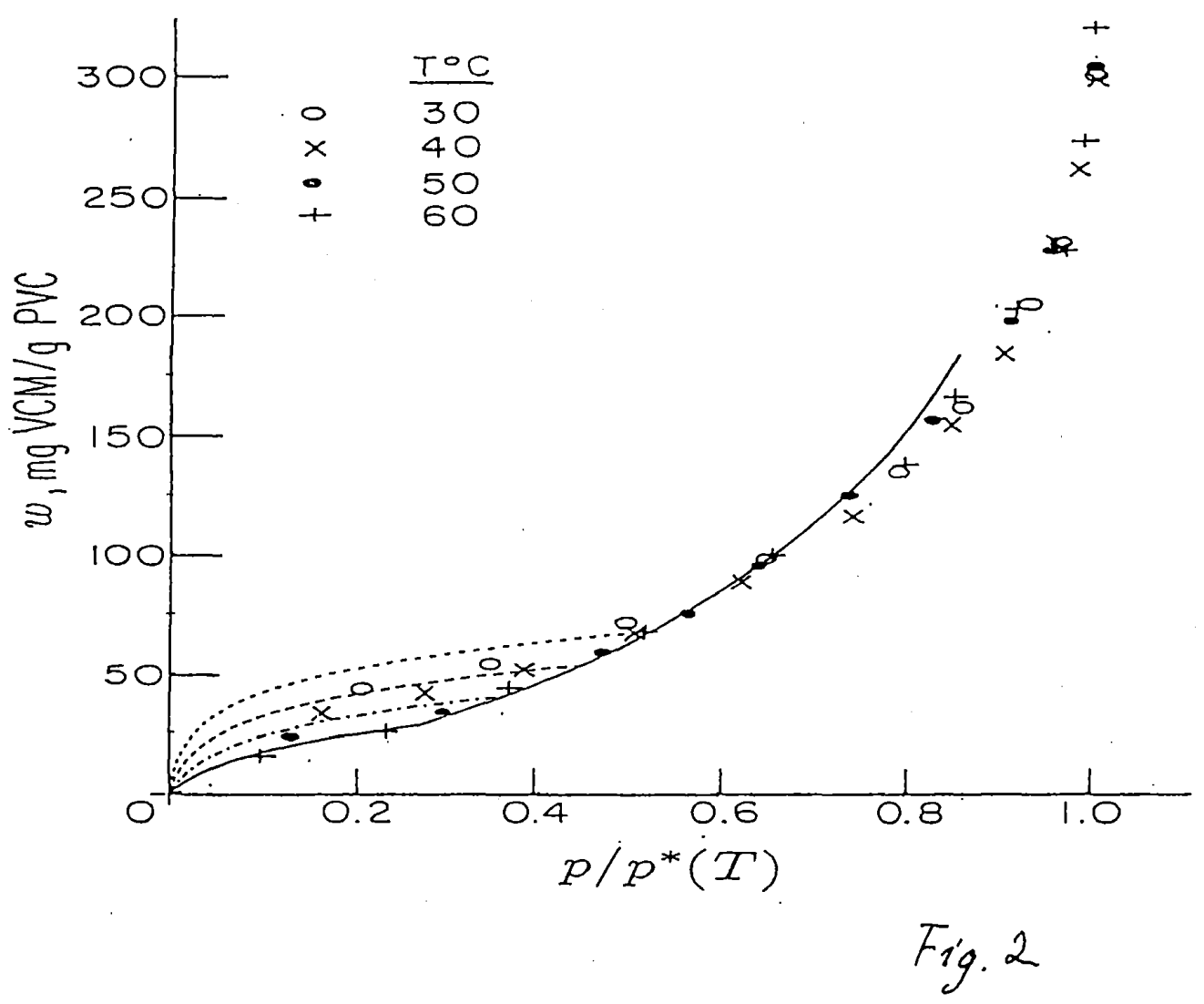

